\title{
Proteolytic enzymes secreted by larval stage of the parasitic nematode Trichinella spiralis
}

\author{
Valentina K. Todorova
}

Institute of Molecular Biology, Bulgarian Academy of Sciences, Acad. G. Bonchev St., Bldg. 21, 1113 Sofia, Bulgaria

Key words: antibody inhibition, excreted/secreted products, larval stage, serine proteinases, Trichinella spiralis

\begin{abstract}
Excretory/secretory products (ES), collected from in vitro cultures of muscle larvae (L1) of Trichinella spiralis (Owen, 1835) were examined for the presence of proteolytic enzymes. Several discrete proteinases in the size range of 25-55 $\mathrm{kDa}$ were identified by substrate gel electrophoresis and were characterised according to $\mathrm{pH}$ optima, substrate specificity and inhibitor sensitivity using azocasein assay. Serine, cysteine and metalloproteinases active at $\mathrm{pH}$ 5-7 were identified. The serine proteinases were found to predominate and some of them were found to be specific for the larval stage of the parasite. The results from the substrate analysis indicated the presence of collagenolytic and elastolytic activities. The proteinase activity was inhibited by $\operatorname{IgG}$ isolated from $T$. spiralis-infected mice, an observation of relevance to understanding host/parasite interactions and, ultimately, the development of anti-Trichinella vaccine.
\end{abstract}

Proteolytic enzymes are receiving increasing attention as biologically important molecules for parasites in a range of biological processes. They are presumably involved in processes such as penetration of host tissues, parasite nutrition, anti-coagulation and evasion of host immune responses (McKerrow 1989). It is now clear that parasite enzymes can stimulate host protective immunity and may be potent allergens (Stromberg 1980, Kennedy et al. 1991, McKeand and Knox 1994).

Trichinella spiralis (Owen, 1835) is a parasitic nematode which is capable of infecting a wide variety of mammals including humans. The complete life cycle of the parasite occurs in a single host and begins when the host consumes infected meat. The life cycle of Trichinella has been well characterised (Despommier 1983) and comprises the adult stage in the host gastrointestinal tract, a migratory phase during which the newborn larvae pass through the blood and lymphatics to the skeletal muscle cells, and encapsulated larvae (L1 larva) in the muscles which represent the infective stage of the parasite. The infective first-stage larva occupies the striated muscle cells, which are radically altered as a result of the infection. The mechanisms by which the larvae penetrate tissues are unknown, although the importance of proteolytic enzymes is suspected (McKerrow 1989, Knox 1994).

Previous investigations showed that the adult Trichinella spiralis secrete in vitro a number of proteinases (Todorova et al. 1995) with optimal activity at $\mathrm{pH}$ 7.5. Serine proteinases predominated and were found to be targets of an antibody response.

The present study concentrates on the proteolytic activity of excretory/secretory products (ES) of T. spi- ralis larvae. The $\mathrm{pH}$ optimum, substrate specificity, inhibitor sensitivity and the effect of antibody, isolated from immune animals, on proteolytic activity were studied.

\section{MATERIALS AND METHODS}

Parasites and preparation of ES. Trichinella spiralis larvae (L1) were isolated by the standard pepsin digestion method (Brand et al. 1952) from the muscles of 10-12-weekold mice, which had been orally infected 28 days previously. Adult parasites were isolated from intestines of mice infected 5 days previously as described elsewhere (Todorova et al. 1995). The parasites were extensively washed in Hank's balanced salt solution (HBSS, Gibco Ltd), supplemented with antibiotics as described before (Todorova et al. 1995). The parasites were maintained for $3-4$ days at $37^{\circ} \mathrm{C}, 5 \% \mathrm{CO}_{2}$ at a concentration of 10000 larvae in $10 \mathrm{ml}$ and 100 adults $/ 10 \mathrm{ml}$ of RPMI 1640, Dutch modification (Gibco Ltd), containing the following additives: $2 \mathrm{mM}$ L-glutamine; $1 \mathrm{mg} / \mathrm{ml}$ glucose; $400 \mathrm{ng} / \mathrm{ml}$ glycyl-1-histidyl-1-lysine; $40 \mu \mathrm{g} / \mathrm{ml}$ glutathione; $5 \mu \mathrm{g} / \mathrm{ml}$ Fungison; $100 \mathrm{IU} / \mathrm{ml}$ penicillin; $100 \mu \mathrm{g} / \mathrm{ml}$ streptomycin; $25 \mu \mathrm{g} / \mathrm{ml}$ gentamycin sulphate and $1 \mathrm{mM}$ sodium pyruvate. Culture supernatants were concentrated, dialysed and stored at $-20^{\circ} \mathrm{C}$. The protein concentration, estimated using a Coomassie Blue-based assay (Pierce Chemical Co), was typically between 70 and $100 \mu \mathrm{g} / \mathrm{ml}$.

Effect of pH on enzyme activity. The effect of $\mathrm{pH}$ on activity against azocasein was tested over the range $\mathrm{pH}$ 4-9, using $0.1 \mathrm{M}$ acetate buffer ( $\mathrm{pH} 4-6$ ), $0.1 \mathrm{M}$ phosphate buffer (pH 5-7) and 0.1 M Tris-Cl buffer ( $\mathrm{pH}$ 7-9). The assay was performed in triplicate.

Enzyme assays. Proteolytic activity was measured spectrophotometrically by use of chromogenic substrates azocasein, azocoll, and elastin-orcein (Sigma Chemicals Co.) as follows: the ES samples $(20 \mu 1)$ were mixed with $5 \mu \mathrm{l}$ 
substrate $(5 \mathrm{mg} / \mathrm{ml})$ and $100 \mu \mathrm{l}$ incubation buffer $(0.1 \mathrm{M}$ citrate/phosphate buffer, $\mathrm{pH} 5$ or $1 \mathrm{M}$ Tris-Cl buffer, $\mathrm{pH} 6$, or $0.1 \mathrm{M}$ Tris- $\mathrm{Cl}, \mathrm{pH}$ 7) and incubated for 16 hours at $37^{\circ} \mathrm{C}$. After precipitation with equal volume of $1 \mathrm{M}$ perchloric acid (for azocasein) or centrifugation (for azocoll and elastinorcein) the absorbance was read at $405 \mathrm{~nm}$ (azocasein) or 540 $\mathrm{nm}$ (azocoll and elastin-orcein). Activities were corrected for non-enzymic hydrolysis by subtraction of the appropriate reagent blank.

Polyacrylamide-substrate gels. Protease activity was monitored also on SDS gels. The procedure was described elsewhere (Todorova et al. 1995). Briefly, $20 \mu \mathrm{l}$ sample diluted with $15 \mu \mathrm{l}$ sample buffer (5\% SDS, 20\% glycerol, $0.01 \%$ bromophenol blue in $0.5 \mathrm{M}$ Tris, $\mathrm{pH} 7$ ) was electrophoresed on $10 \%$ or $5-25 \%$ polyacrylamide gradient gels, copolymerised with $0.1 \%$ gelatine (Gibco Ltd). After washing to remove the SDS, electrophoresis gels were incubated overnight in $0.1 \mathrm{M}$ Tris buffer, $\mathrm{pH} 7$ at $37^{\circ} \mathrm{C}$. Zones of proteolysis were visualised by Coomassie staining $(0.1 \%$ Coomassie blue R-250 in 25\% methanol, $10 \%$ acetic acid and $1 \%$ glycerol).

Inhibitor sensitivity. The sensitivity to protease inhibitors was tested by determining the hydrolysis of azocasein after preincubation with protease inhibitors. Inhibitors specific for serine proteinases: phenylmethane-sulphonyl-fluoride (PMSF), $1 \mathrm{mM}$ and tosyl lysyl chloromethyl ketone (TLCK), $1 \mathrm{mM}$; cysteine proteinases: L-trans-epoxysuccinyl-leucylamide-4-guanidino-butane (E64), $50 \mu \mathrm{m}$ and N-ethylmaleimide (NEM), $1 \mathrm{mM}$; metalloproteinases: orthophenanthroline (1,10 Phe), $2 \mathrm{mM}$ and ethylenediaminetetraacetic acid (EDTA), $2 \mathrm{mM}$; aspartyl proteinases: pepstatin, $2 \mu \mathrm{M}$ and the thiol protecting agent DTT, $2 \mathrm{mM}$ were used. Routinely, $20 \mu 1$ of sample were preincubated for 1 hour at room temperature with $3 \mu \mathrm{l}$ of inhibitor in $100 \mu \mathrm{l}$ buffer, to give the above concentrations of the inhibitors and the enzyme activities were determined as described above with azocasein as substrate. All inhibitors were purchased from Sigma Chemicals Co.

Anti-T. spiralis antiserum. Mouse anti-T. spiralis antisera were prepared from mice infected 3 times with 150 larvae each. Sera were collected 21 days after the final infection. IgG was purified from sera by affinity chromatography using Protein G-Sepharose 4B (Sigma Chemicals Co) according to the manufacturer's instructions.

Inhibition of proteinases activity by antibody. The inhibition of protease activity by IgG was measured spectrophotometrically using azocasein as described elsewhere (Todorova et al. 1995). Briefly, the ES samples were preincubated with up to $100 \mu \mathrm{g} \mathrm{IgG}$ isolated from sera of normal animals and animals infected with $T$. spiralis for 1 hour at $37^{\circ} \mathrm{C}$ and the effect on the azocasein degradation was measured as described above.

Western blotting. For Western blot analysis ES were electrophoresed in a $10 \%$ SDS-PAGE and electroblotted overnight at $4{ }^{\circ} \mathrm{C}$ onto nitrocellulose in Tris-glycine buffer, containing $0.1 \%$ SDS using a Mini-Trans-blot transfer cell (Bio-Rad). The blots were blocked for 1 hour in 5\% skimmed milk in $0.1 \%$ Tween in Tris-buffered saline. The mouse antiT. spiralis $\operatorname{IgG}$ was added at 1:100 dilution in the buffer described above for $90 \mathrm{~min}$. After washing (three times) the blots were incubated with rabbit anti-mouse alkaline phosphatase-conjugated IgG (1:1000), washed again and the reaction was developed with NBT/BCIP [66 $\mu 1$ NBT $(0.3 \mathrm{mg}$ in $1 \mathrm{ml}$ of $70 \%$ DMF $)$ and $33 \mu \mathrm{l}$ BCIP $(0.15 \mathrm{mg}$ in $1 \mathrm{ml}$ of $100 \% \mathrm{DMF}$ ) up to $10 \mathrm{ml}$ with alkaline phosphatase buffer (100 mM NaCl, $5 \mathrm{mM} \mathrm{MgCl}$, $100 \mathrm{mM}$ Tris, pH 9.5)].

\section{RESULTS}

Proteinases pH optimum and molecular sizes. The proteolytic enzymes in the larval ES were found to degrade azocasein over a broad $\mathrm{pH}$ range (Fig. 1). Peak activity occurred at $\mathrm{pH} 7$, with high activities also at $\mathrm{pH}$ 5 and $\mathrm{pH} 6$.

Gelatin-substrate gel analysis showed zones of proteolysis at approximately 25 (a doublet), 35, 40, and $55 \mathrm{kDa}$ (Fig. 2, lane 1). The proteolytic activity of larval ES was compared with that of adult ES (Fig. 2, lane 3). Adult parasites showed proteolysis at approximately 18 , 25 (a doublet), 38, 40, and $42 \mathrm{kDa}$. Proteinases with approximate molecular sizes of 25 and $40 \mathrm{kDa}$ were present in the ES of both larvae and adult parasites, while enzymes with molecular sizes of approximately 35 and $55 \mathrm{kDa}$ for larvae, and 18, 38 and $42 \mathrm{kDa}$ for adults, were stage-specific. In the present study we have used $5-25 \%$ gradient gels instead of homogeneous $10 \%$ gels we used before (Todorova et al. 1995) and obtained a better resolution of the proteolytic profile in the zone of 15-60 kDa. Here we found several discrete proteinases of adult ES in the zone of $25-42 \mathrm{kDa}$ which were not detected in the homogeneous gels.

Table 1. Proteolytic activity of ES of Trichinella spiralis larvae (L1). Data are expressed as change in absorbance (absorbance units $\times 10^{-3} / 16$ h.). Mean values of three observations are presented.

\begin{tabular}{|l|l|r|r|r|}
\hline $\begin{array}{l}\text { Type of enzyme } \\
\text { activity indicating }\end{array}$ & Substrate & pH 5 & pH 6 & pH 7 \\
\hline General & Azocasein & 52.3 & 88.2 & 137.3 \\
Collagenase & Azocoll & 183.2 & 108.7 & 65.3 \\
Elastase & Elastin-orcein & 95.1 & 128.2 & 172.1 \\
\hline
\end{tabular}

Table 2. The effect of protease inhibitors on proteolytic activity of Trichinella spiralis larval ES assessed in azocasein degradation assay. The inhibition of proteolytic activity is expressed as a reduction in absorbance compared to an inhibitor-free control. The means of two observations are shown.

\begin{tabular}{|l|c|}
\hline Inhibitor & Inhibition $\%$ \\
\hline PMSF & 62 \\
TLCK & 37 \\
E64 & 12 \\
NEM & 0 \\
1,10 Phe & 15 \\
EDTA & 7 \\
pepstatin & 0 \\
DTT & 0 \\
\hline
\end{tabular}


Substrate specificity. The proteolytic activities of

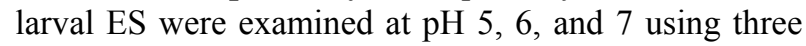
chromogenic substrates: azocasein, azocoll and elastinorcein (Table 1). The results indicated that larval ES contained collagenolytic and elastolytic activities. The collagenolytic activity was maximal at $\mathrm{pH} 5$, while elastolytic had a maximal value at $\mathrm{pH}$ 7. The activity against the general proteinase substrate azocasein was maximal at $\mathrm{pH} 7$.

Inhibitor sensitivity of ES proteinases. The effects of various inhibitors on the proteolytic activity of larval ES against azocasein as a substrate are shown in Table 2. ES proteinases were markedly inhibited by serinespecific inhibitors PMSF (62\%) and TLCK (37\%). Inhibition was established also with E64 (12\%) and 1,10 Phe (15\%), indicating the presence of cysteine and metalloproteinases. The predominance of serine type of proteinases was confirmed by the substrate gel electrophoresis. After preincubation with the serine specific inhibitor PMSF the protease activities of larval ES in the zone between 25 and $40 \mathrm{kDa}$ were completely abolished (Fig. 2, lane 2). The effect of PMSF on the proteolytic activity of larval ES was compared with that on the adult parasite ES. Most of the proteinase activities in the ES of adult parasites were also totally or partially inhibited. (Fig. 2, lane 4). Proteolysis at approximately $25 \mathrm{kDa}$ was totally inhibited and others were reduced.

Antibody inhibition of ES proteinases. The effect of IgG from T. spiralis-infected and control (uninfected) animals on the proteolytic activity of larval ES was assessed in azocasein degradation assay. The results are presented in Fig. 3. Preincubation of ES with up to 100 $\mu \mathrm{g} \mathrm{IgG} \mathrm{from} \mathrm{T.} \mathrm{spiralis-infected} \mathrm{animals} \mathrm{showed} \mathrm{a} 63 \%$ reduction of azocasein-proteolysis compared with about $10 \%$ reduction with normal IgG. Gelatin-substrate gels confirmed the antibody-mediated inhibition of proteolytic activity of larval ES, although there was considerable variation between gels (not shown).

Antibody recognition of ES components. Using Western blot analysis we found that a component of larval ES with molecular size of approximately $35 \mathrm{kDa}$ was recognised by $\operatorname{IgG}$ isolated from antisera of mice infected with $T$. spiralis (Fig. 4).

\section{DISCUSSION}

Proteolytic enzymes secreted by parasites are thought to play a key role in the processes of penetration and migration through the host tissues. It has been stated that all of the proteinases secreted by tissue-invading parasites fall into two of the classes of proteinases serine and metallo (McKerrow 1989). Proteinases of these classes have been demonstrated in studies on the secreted products of Anisakis simplex (Sakanari and McKerrow 1989), Onchocerca lienalis, O. cervicalis

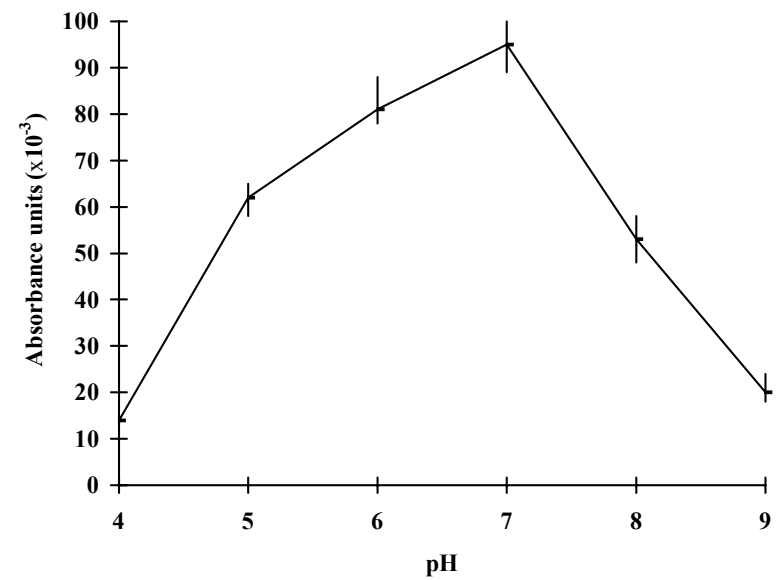

Fig. 1. The effect of $\mathrm{pH}$ on azocasein degradation by proteinases in larval ES of Trichinella spiralis. The means of three observations are shown, with error bars representing the S.D.

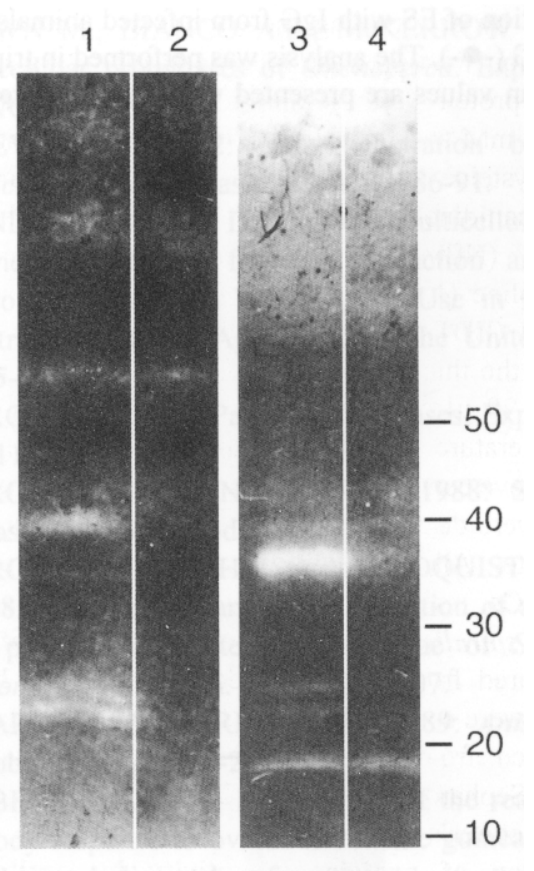

Fig. 2. Proteolytic activities of larval (lane 1) and adult (lane 3) Trichinella spiralis ES. Preincubation of ES with serine protease inhibitor PMSF prior to electrophoresis (larval ES, lane 2; adult ES, lane 4) showed that the proteolysis is totally or partially inhibited.

and O. cervipedis (Lackey et al. 1989), Schistosoma mansoni (McKerrow et al. 1985), Ancylostoma caninum (Hotez et al. 1985), Dictyocaulus viviparus (Britton et al. 1992) and adult Trichinella spiralis (Todorova et al. 1995). Criado-Fornelio et al. (1992) established the 


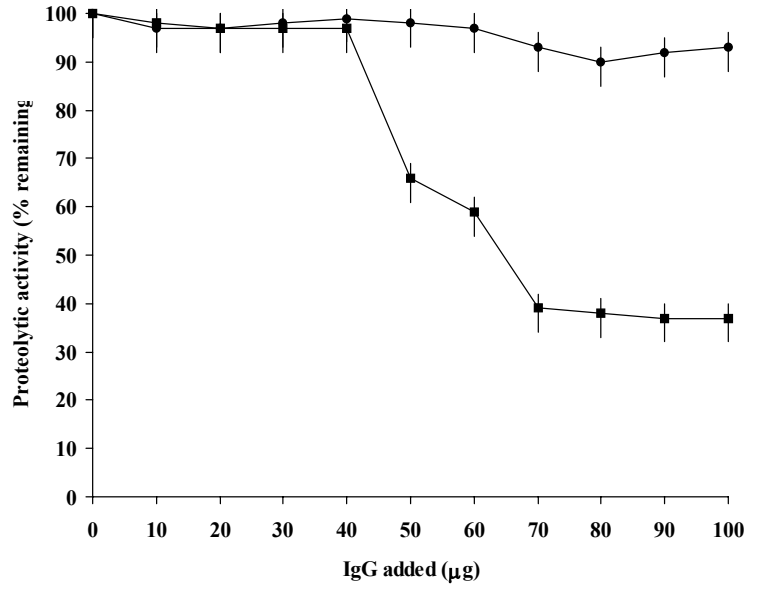

Fig. 3. The effect of IgG isolated from infected and uninfected mouse sera on the proteolytic activity of larval Trichinella spiralis ES assessed in azocasein degradation assay. Preincubation of ES with IgG from infected animals (-ш-) and normal IgG (-๑). The analysis was performed in triplicate and of the mean values are presented with error bars representing the S.D.

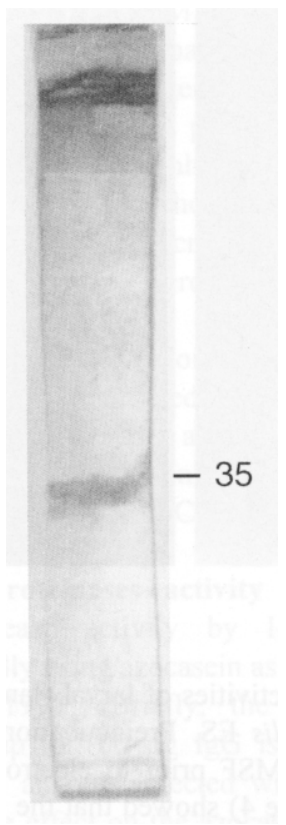

Fig. 4. Western blot analysis of larval ES of Trichinella spiralis. Following SDS-PAGE of the ES the blots were probed with $\operatorname{IgG}$ isolated from sera of $T$. spiralis-infected and normal mice. No reaction was found with IgG isolated from normal mouse sera (not shown). presence of proteolytic activities in the ES of $T$. spiralis larvae, but the molecular sizes, $\mathrm{pH}$ optimum, and type of the proteinases have not been defined. In this study, the proteolytic activity of the in vitro released ES of larval stage (L1) of $T$. spiralis were examined according to their $\mathrm{pH}$ optimum, activity against some protein substrates and inhibitor sensitivity. The inhibitor studies showed that serine proteinases predominated. ES proteinases degraded azocasein, azocoll and elastinorcein over a broad $\mathrm{pH}$ range with peak activities at $\mathrm{pH}$ 5 for the degradation of azocoll and $\mathrm{pH} 7$ for azocasein and elastin-orcein. These results would argue for the presence of collagenolytic and elastinolytic activities of ES of $T$. spiralis larvae. With respect to the possible function of secreted parasitic proteinases in vivo, it has been proposed that collagenolytic and elastolytic activities are consistent with tissue migration (Matthews 1982, McKerrow et al. 1988, Chavez-Olortegui et al. 1992). These proteinases might also be active in the processes of parasite transformation and counterimmunity.

The present study established that antibody stimulated by infection can inhibit the proteolytic activity of ES. Antibody-mediated inhibition of parasite proteinases has been reported in investigations on experimental infection with Schistosoma mansoni (Auriault et al. 1981), Ascaris suum (Knox and Kennedy 1988), Dictyocaulus viviparus (Britton et al. 1992), Haemonchus contortus (Knox et al. 1993), Trichinella spiralis (Armas-Serra et al. 1995a, Todorova et al. 1995) and it is possible that the antibody response can minimise the direct damage of host tissues by inhibition of proteinase activity.

A component of larval ES was recognised by $\operatorname{IgG}$ isolated from anti-Trichinella spiralis serum as shown by Western blot analysis. The presence of a proteinase with the same molecular size was found by means of substrate SDS-PAGE and it could be the same, which was recognised by the immune antibody. Moreover, a $35 \mathrm{kDa}$ proteinase with properties of both serine and cysteine proteinases has been purified from ES of T. spiralis muscle larvae (Armas-Serra et al. 1995a, b) and this has been shown to have antigenic properties. The recognition of this in vitro secreted suspected serine protease by $\mathrm{IgG}$ isolated from antisera of mice infected with $T$. spiralis indicates that it is a target of the immune response to infection with $T$. spiralis and suggests that it is secreted also in vivo.

In summary, this study showed that the infective larvae of $T$. spiralis secrete in vitro a number of proteinases predominantly of the serine type. These enzymes showed azocollytic and elastolytic activities, probably implicated in tissue penetration. They are targets of inhibitory host antibody responses in vivo, which might presumably impair parasite survival. A serine protease with molecular size of approximately 
$35 \mathrm{kDa}$ is recognised by immune antibody and is specific for the larval stage of the parasite. The information provided could be valuable in further investigations, including purification techniques, design of gene cloning strategies and development of diseasestage markers or diagnostic reagents.

Acknowledgement. This investigation was supported by Bulgarian National Science Fund (L-715).

\section{REFERENCES}

ARMAS-SERRA C., GIMENES-PARDO C., BERNADINA W.E., RODRIGUEZ-CAABEIRO F. 1995a: Antibody response to a protease secreted by Trichinella spiralis muscle larvae. Parasitol. Res. 81: 540-542.

ARMAS-SERRA C., GIMENEZ-PARDO C., JIMENEZGONZALEZ A., BERNADINA W.E., RODRIGUEZCAABEIRO F. 1995b: Purification and preliminary characterization of a protease from the excretion-secretion products of Trichinella spiralis muscle-stage larvae. Vet. Parasitol. 59: 157-168.

AURIAULT C., PESTEL J., JOSEPH M., DESSAINT J.P., CAPRON A. 1981: Interaction between macrophages and Schistosoma mansoni schistosomula: role of IgG peptides and aggregates on the modulation of B-glucoronidase release and cytotoxity against schistosomula. Cell. Immunol. 62: 15-27.

BRAND T., WEISTEIN P., MEHLAN B., WEINBACH E. 1952: Observation on the metabolism of bacteria-free larvae of Trichinella spiralis. Exp. Parasitol. 1: 245-255.

BRITTON C., KNOX D.P., CANTO G.J., URQUHART G.M., KENNEDY M.W. 1992: The secreted and somatic proteinases of the bovine lungworm Dictyocaulus viviparus and their inhibition by antibody from infected and vaccinated animals. Parasitology 105: 325-333.

CHAVEZ-OLORTEGUI C., RESENDE M., TAVARES C.P.A. 1992: Purification and characterization of a $47 \mathrm{kDa}$ protease from Schistosoma mansoni cercarial secretions. Parasitology 105: 211-218.

CRIADO-FORNELIO A., ARMAS-SERRA C., GIMENEZPARDO C., CASADO-ESCRIBANO N., JIMENEZGONZALEZ A., RODRIGUEZ-CAABEIRO F. 1992: Proteolytic enzymes from Trichinella spiralis larvae. Vet. Parasitol. 45: 133-140.

DESPOMMIER D.D. 1983: Biology. In: W.C. Campbell (Ed.), Trichinella and Trichinellosis. Plenum Press, New York, 75-142.

HOTEZ P.J., TRANG L.N., McKERROW J.H., CERAMI A. 1985: Isolation and characterisation of proteolytic enzyme from the adult hookworm Ancylostoma caninum. J. Biol. Chem. 260: 7343-7348.

KENNEDY M.W., WASSOM D.L., McINTOSH A.E., THOMAS J.C. 1991: H-2 (I-A) control of the antibody repertoire to secreted antigens of Trichinella spiralis in infection and its relevance to resistance and susceptibility. Immunology 73: 36-43.

KNOX D.P. 1994: Parasite enzymes and the control of roundworm and fluke infestation in domestic animals. Brit. Vet. J. 150: 319-338.

KNOX D.P., KENNEDY M.W. 1988: Proteinases released by the parasitic larval stages of Ascaris suum and their inhibition by antibody. Mol. Biochem. Parasitol. 28: 207216.

KNOX D.P., REDMOND D.L., JONES D.G. 1993: Characterisation of the proteinases in extracts of adult Haemonchus contortus, the ovine abosomal nematode. Parasitology 106: 395-404.

LACKEY A., JAMES E.R., SAKANARI J.A., RESNIK S.D., BROWN M., BIANCO A.E., McKERROW J.H. 1989: Extracellular proteinases of Onchocerca. Exp. Parasitol. 68: 176-185.

MATTHEWS B.E. 1982: Skin penetration by Necator americanus larvae. Parasitol. Res. 68: 86-91.

McKEAND J.B., KNOX D.P. 1994: Multicellular parasite vaccine. In: Manual for the Production and Quality Control of Veterinary Vaccines for Use in Developing Countries. Food and Agriculture of the United Nations, pp. $15-56$.

McKERROW J.H. 1989: Parasite proteinases. Exp. Parasitol. 68: 111-115.

McKERROW J.H., DOENHOFF M.J. 1988: Schistosome proteases. Parasitol. Today 4: 334-340.

McKERROW J.H., PINO-HEISS S., LINDQUIST R., WERB Z. 1985: Purification and characterisation of an elastinolytic proteinase secreted by cercariae of Schistosoma mansoni. J. Biol. Chem. 260: 3703-3707.

SAKANARI J.A., McKERROW J.H. 1989: Anisakis. Clin. Microbiol. Rev. 2: 278-284.

STROMBERG B.E. 1980: Potentiation of the reaginic (IgE) antibody response to ovalbumin in the guinea pig with a soluble metabolic product from Ascaris suum. J. Immunol. 125: 833-835.

TODOROVA V.K., KNOX D.P., KENNEDY M.W. 1995: Proteinases in the excretory/secretory products (ES) of adult Trichinella spiralis. Parasitology 111: 201-208. 